\title{
Adalékok a Csehszlovák Köztársaság magyar nyelvű siketoktatás-történetéhez ${ }^{1}$
}

\author{
Szepessyné Judik Dorottya - Horváth Kinga
}

\section{Addenda to the history of teaching the Deaf in Hungarian language in the Czechoslovak Republic \\ Abstract}

In this study we present the educational-historical data of the only institute for the Deaf operating in the Czechoslovak Republic, in Komárom (Komárno), between 1920 and 1938. By 1918 a unified deaf education network had been established in the territory of historical Hungary in the Austro-Hungarian Monarchy where 16 institutes for the Deaf were run, covering the entire area of the country. Out of these, three were located in Upper Hungary (Felvidék): in Jolsva (Jelšava), in Körmöcbánya (Kremnica) and in Pozsony (Bratislava); in the Carpathian region, school-age deaf learners were expected in an institute for the Deaf in Ungvár (Uzhhorod). This system disintegrated with the Trianon Peace Treaty. The institutes located at Pozsony (Bratislava), Körmöcbánya (Kremnica), Jolsva (Jelšava) and Ungvár (Uzhhorod) became organisations located in the Czechoslovak Republic from the former Hungarian institutes for the Deaf. A Hungarian-language, newly established school for the Deaf was run in Komárom (Komárno) between 1920 and 1938 in the territory of the Czechoslovak Republic. After the First Vienna Award, the aforementioned institute for the Deaf was moved to Losonc (Lučenec). While researching the history of the Hungarian-language Institute for the Deaf of Komárom (Komárno), it turned out that the sources referring to operation and history (statistics, archive, library, press history) are scanty, I therefore used the term addenda in the title.

Keywords: deaf education; Czechoslovak Republic; Komárom (Komárno)

Kulcsszavak: siketoktatás; Csehszlovák Köztársaság; Komárom

Subject-Affiliation in New CEEOL: Social Sciences - Education - History of Education

DOI: 10.36007/eruedu.2021.3.026-034

1 Jelen tanulmány a Kisebbségi helyzet, identitás, oktatás - a szlovákiai magyar kisebbségi identitás iskolai önérvényesitési stratégiái címü VEGA-kutatás (Témavezető: Németh András, regisztrációs szám: 1/0117/19) keretében készült. 


\section{Bevezető gyanánt}

A tanulmányban a Csehszlovák Köztársaság Komáromban 1920 és 1938 között működő siketoktatási intézményének oktatástörténeti adatait tesszük közzé. Jelen információink szerint a fent nevezett intézetnek a gyógypedagógiai, a nevelés-, illetve oktatástörténeti szakirodalomban nem történt meg a teljes körü történeti feldolgozása. Azért is érdemel figyelmet az intézet sorsa, mivel kizárólag ebben az intézetben végezhették magyar nyelven a tanulmányaikat a csehszlovákiai magyar anyanyelvü siket tanulók.

\section{Felvidéki siketoktatási kezdeményezések a 19. század első felében}

1802-ben a történeti Magyarországon, Európában a tizedikként létrejött a váci siketintézet, amely a kiegyezés koráig gyakorlatilag monopolhelyzetben volt a siketoktatás területén. Igaz, ezt megtörte a magánfinanszírozású pozsonyi siketintézet 1833-as alapítása. Müködéséröl 1839-ben találunk egy részletes tudósítást a Hírnök címlapján, amelyben olvasható, hogy abban az évben 19 siket tanuló járt az iskolába. A Nemzeti Ujság 1842-ben megjelent cikkében azonban már összevont siketek és vakok intézetéröl olvashatunk (Hírnök 1839; Nemzeti Ujság 1843).

Időközben 1835-ben Liptószentmiklóson Mauksch Mór jóvoltából szintén megvalósult a siket gyermekek formális oktatása, kezdetben három tanítvánnyal. Mauksch Mórt családi helyzete (sógora kilenc gyermeke közül négy volt siket) predesztinálta arra, hogy a siketek oktatására képezze magát. 1840-ben Liptó vármegye székháza nagytermében az általa hangzó beszédre tanított növendékeket bemutatta a közgyülésen. Szentiványi Adolf megyei föjegyző ennek hatására lemondott félévi fizetéséről az intézet javára. Az intézet évről évre egyre nagyobb látogatottságnak örvendett. Mauksch Mór hírneve az 1840-es évek elején már oly nagy volt, hogy külföldröl is kapott tanitványokat, kiknek részére kis internátust is berendezett. 1842-ben bemutatta tanitványait a Magyar Orvosok és Természettudósok besztercebányai gyűlésén. Intézetének kiépítése, fenntartása azonban anyagi nehézségekbe ütközött, ezért egy ízben állásért folyamodott a váci intézethez, de sikertelenül. Samuel Heinicke német pedagógushoz hasonlóan ő is a hangzó beszédre helyezte a hangsúlyt a jelnyelv helyett a siketek oktatásánál. Mauksch Mór végigharcolta a szabadságharcot és harctéren szerzett sebesülése következtében halt meg 1848-ban, 40 éves korában. Sírkövére a zsoltárból vett következő idézet van vésve: „A kicsinyek szájából alapítottad meg hírnevedet”. Egykori feljegyzések szerint Mauksch Mór a siketoktatás körül szerzett tapasztalatait összegyüjtve terjedelmes kéziratot hagyott hátra, melyben leírta módszerét. Ezt a kéziratot fia, Mauksch Sámuel meg akarta jelentetni, de anyagi okok miatt ez nem történt meg és a kézirat elkallódott. Mauksch Sámuel apja halála után átvette ugyan a liptószentmiklósi intézet vezetését, de anyagi okok miatt már 1849-ben megszünt (Herzog 1894, 180). 


\section{Dualizmuskori oktatási körkép a Felvidéken}

A Felvidéken elöször 1901-ben Jolsván, 1903-ban Körmöcbányán, majd 1905ben Pozsonyban jött létre siketintézet. A századfordulón még kevés intézet állt rendelkezésre az igényekhez képest. Az 1900-1901. évi tanévben csak nyolc iskola müködött (Budapesten kettő, Vácon, Kecskeméten, Temesváron, Kaposváron, Aradon, illetve Kolozsváron egy), ahol összesen 494 (!) diák végzett. Országos szinten több mint 4000 siket gyermek nem részesült semmiféle oktatásban és így ennek következtében helyzetük teljesen kiszolgáltatottá vált felnőtt korba lépve (Klis 1901, 34).

A körmöcbányai intézet iskolai értesitőjében olvasható prominensen megfogalmazva a siketiskolák küldetése: „A cél az, hogy a siketnéma ne szoruljon mások istápolására, hanem tartsa fen magát a keresményéböl. A siketnémák intézetének czélszerű nevelési és oktatási rendszer alkalmazásával, vagyis a hangzó beszéd használatának és kellő reál ismereteknek alkalmazásával a siketnémát önállóvá kell képeznie és fel kell őt szabadítania azon gyámság alól, mely életét különben is nagyon szűk korlátok közé szorítja" (Hercsuth 1904, 14-15).

A három intézet biztosította a felvidéki siket tanulók számára az oktatást. Az intézeti felvételi hirdetményekben pontosan rögzítették, mely vármegyéből várják elsősorban a jelentkezőket. Az iskolai értesítőkből kitűnik, hogy a körmöcbányai intézetbe elsősorban Bars, Turóc, Zólyom, Liptó, Árva, Trencsén vármegyékből, a jolsvai iskolába nagyrészt Gömör-Kishont, Szepes és Sáros vármegyékböl, a pozsonyi intézetbe javarészt Pozsony városából, Pozsony és Nyitra vármegyékből vettek fel tanulókat. A kincstári ingyenes helyekre az ország bármely részéböl vettek fel tanulókat, ezekröl az intézet felügyelöbizottsága döntött. Az intézetbe minden olyan, 7. életévét betöltött és 10. életévét be nem töltött gyermeket vettek fel, aki rendelkezett „,siketnémaságot igazoló tiszti orvosi bizonyitvánnyal”, illetve himlőoltási bizonyitvánnyal. Segélyezésre csak megfelelő vagyonigazolással voltak jogosultak a diákok. Az oktatás 8 évig tartott.

A következő tantárgyakat tanították az „élőszó-beszéd módszere használatával és a jelbeszéd kizárásával”: kiejtési gyakorlatok írással és olvasással, beszédtanítás, leíró szemléleti oktatás, fogalmazás, olvasás, hit- és erkölcstan, számtan, természetrajz, természettan, földrajz, történelem, alkotmánytan, szépírás rajz, kézimunka (kézügyességi gyakorlatok - slöjd - és női kézimunka), torna.

A tanítás nyelve egységesen a magyar volt. Annyi engedményt tettek, hogy igazgatói jóváhagyás birtokában az érdeklődő diáknak valamelyik intézeti tanár csak külön dijjazás ellenében oktathatott idegen nyelvet. Az egyes tantárgyaknál tanítandó tananyagot és az ehhez alkalmazott módszereket a vallás- és közoktatásügyi miniszter által kiadott 1900. évi 16822. számú és az 1903. évi 17550. számú rendeletei alapján alkalmazták (Körmöcbányai siketintézet értesítője 1905-1906, 26). A növendékek száma egy osztályban 8-15 fö lehetett.

Az Osztrák-Magyar Monarchia történeti Magyarországán 1918-ig egységes siketoktatási rendszer működöt 16 siketintézettel, lefedve az ország egész területét. Ez a rendszer azonban a trianoni békeszerződéssel felbomlott. 


\section{Az 1919-1938 közötti csehszlovák oktatásügyi háttér}

Az újonnan megalakult csehszlovák államalakulatnak szembesülnie kellett az Osztrák-Magyar Monarchia kettős örökségével a szlovákiai területen folyó siketoktatási rendszert látva. A cseh és a szlovák országrész más-más oktatási rendszert örökölt. A cseh intézetekben osztrák, a szlovák iskolákban pedig magyar minta szerint folyt az oktatás, és ugyanez feltételezhető a két országrész siketiskoláira vonatkozólag is. Elöbbiben az 1869. évi 201-es iskolai törvény volt hatályban, utóbbiban pedig az 1868. évi 38. oktatási törvény. Csehszlovákia létrejöttekor a hatalomra kerülö politika az Osztrák-Magyar Monarchiától örökölt iskolarendszer leépítését akarta megvalósítani (Popély 1998, 29; Pukánszky 2019, 34).

A Csehszlovák Köztársaság szlovákiai országrészén müködött a pozsonyi, a körmöcbányai, a jolsvai és az ungvári intézet. A fentiekből adódóan az állami siketoktatási - újabban megjelenő kifejezéssel: hallássérült-oktatási - rendszer új jogi szabályozást igényelt: az intézmények szervezeti felépítését, azok tartalmi fókuszát és a csehszlovák tantervekkel való ellátását érintve. Így akarták elérni, hogy a hallássérült gyermekek megtanuljanak a szüleik anyanyelvén - szlovákul - beszélni. Ennek megoldására az Oktatásügyi és Nemzeti Népmüvelődési Minisztérium és a prágai Szociálisügyi Minisztérium a Siketek Gondozásának Egyesületét, az egyesületnek - a prágai Výmol Intézetben dolgozó - vezető szakértőit vonta be (Pleva 1994, 49).

Ennek köszönhetöen 1919. szeptember 6-án (37 580/1919-es szám alatt) megjelent a prágai Oktatási és Nemzeti Népművelődési Minisztériumnak a Szociálisügyi Minisztériummal együtt kiadott rendelete (Věstník ministerstva školství a národní osvěty 37.580. 6/IX. 1919) „,a siketnéma állami intézetek szervezeti statútumáról", mely az oktatás fö céljának a hallássérülteknek a halló társadalomba való integrációját tüzte ki (Vojtechovský 2011, 163; Vavreková 2014, 501).

Ahogy a rendelet első paragrafusából értelmezhető: legfőképpen a hangzó beszéd elsajátíttatásával, az ő készségeikhez igazodó tudás közvetítésével próbálták a nevezett célt elérni. A rendelet második paragrafusa szerint a tanköteles kort elért gyermekek a 7 éves kort betöltve elöször egy előkészitő osztályba kerültek. Ennek elvégzését követöen kezdhették meg a nyolc évfolyamos képzést. A IV. fejezetben az oktatás és a tanítás szabályozásáról olvashatunk. A tanulóknak ugyanazokat az ismereteket, készségeket kellett elsajátítani, mint ami az elemi népiskolákra volt jellemző. Ebben kimondták, hogy a tananyag és a tanterv azonos az épérzékűek tananyagával és a kézműves készségek fejlesztésére fókuszáltak (kertészet és mezőgazdaság, asztalosmunkák, ruhakészités és cipőkészítés, könyvkötés, esztergálás, faragás és kosárfonás, modellezés stb.) a számukra kialakított mühelyekben. Kimondta, hogy a 4. osztályig ugyanazon tanítók legyenek a gyerekek mellett, aztán felső tagozatban már más tanárok is tanithatnak. A nyolc évfolyam elvégzése után a hallássérült tanulók szakmunkás-bizonyitványt kaptak, a megfelelö kézmüves terület bejelölésével.

A rendelet hangsúlyozta, hogy a hallássérült tanulók sikeres oktatását a házirend és a tanterv pontos betartása segíti elö. A 20. paragrafusban az oktatás módszerét egyértelmüen a hangzó beszédben, azaz az orális módszerben jelölte ki. A 21. 
paragrafusban rögzitette, hogy a szlovákiai siketintézetek tannyelve a csehszlovák (česko-slovenský). A magyar nemzetiségű gyermekek számára Jolsván külön tagozatot, illetve a ruszin nemzetiségű gyermekek részére pedig Ungváron szintén külön tagozatot létesítenek. A szlovákiai németek számára nem létesítettek külön osztályokat, őket Morva-, illetve Csehország iskoláiban helyezték el.

A 25. paragrafus szerint a tanulás ingyenes volt. A bentlakásos iskolákban elhelyezett tanulók a szállásért tanévenként 1600 koronát fizetnek ki.

Az intézmények legföbb feladata gyanánt a helyes, artikulált beszéd megtanítását, annak gyakoroltatását, beszédértést, a halló társadalomban szükséges kommunikáció elsajátításának megtanítását jelölte ki. Ennek érdekében az 1-4. osztályban kizárólag ehhez kapcsolódó tantárgyakat tanultak a hallássérült gyermekek: kiejtési gyakorlatok írással és olvasással, beszédtanitás, leíró szemléleti oktatás, fogalmazás, olvasás. A tantárgyak óraszámát is szabályozta a rendelet, az alábbi óraszámok voltak az egyes tantárgyak esetében elöírva (az 1. táblázatban az eredeti nyelvben rögzitettük a tantárgyakat és mellette a magyar fordítást):

\begin{tabular}{|l|l|l|l|l|l|l|l|l|}
\hline \multirow{2}{*}{ Tantárgyak } & \multicolumn{9}{|c|}{ Tř́dy (osztály) } \\
\hline & I. & II. & III. & IV. & V. & VI. & VII. & VIII. \\
\hline Náboženstvi (Vallás) & & & 3 & 3 & 3 & 3 & 3 & 3 \\
\hline Jazyk vyučovací: tanítási nyelv & & & & & & & & \\
\hline a) hláskováni (cvič. výsl.) (kiejtés) & 16 & $6 / 2$ & & & & & & \\
\hline b) řeč (věcné učeni) (beszéd) & & 13 & 14 & 13 & & & & \\
\hline c) řeč obcovaci (rétorika) & & & & & 3 & 3 & 3 & 3 \\
\hline d) čtení (olvasás) & & & & & 3 & 3 & 4 & 4 \\
\hline e) mluvnice (nyelvtan) & & & & & 4 & 4 & 3 & 4 \\
\hline f) sloh (fogalmazás) & & & & & 2 & 2 & 2 & 2 \\
\hline Počty (számtan) & & 2 & 3 & 4 & 4 & 4 & 4 & 4 \\
\hline Zeměpis (földrajz) & & & & & 2 & 2 & 2 & 2 \\
\hline Dějepis (történelem) & & & & & & & 2 & 2 \\
\hline Př́rodopis (természettudomány) & & & & & & 2 & 2 & 2 \\
\hline Př́rodozpyt (természetismeret) & & & & & & 1 & 2 & 2 \\
\hline Krasopis (szépírás) & 2 & 2 & 1 & 1 & 1 & 1 & & \\
\hline Kreslenín (rajzolás) & & & & & & & & \\
\hline a) volnou rukou (szabad kézzel) & 2 & 2 & 2 & 3 & 3 & 3 & 3 & 3 \\
\hline b) rýsováni (szerkesztés) & & & & & & & 1 & 1 \\
\hline Tělocvik (testnevelés) & 2 & 2 & 2 & 2 & 2 & 2 & 2 & 2 \\
\hline $\begin{array}{l}\text { Ruční práce chlapcú a divek } \\
\text { (kézimunka) }\end{array}$ & 2 & 3 & 3 & 3 & 4 & 4 & & \\
\hline
\end{tabular}

1. táblázat: A hallássérült gyermekek iskoláinak tanterve 1919-töl Csehszlovákiai területén (forrás: Věstník ministerstva školství a národní osvěty. 37.580. 6/IX. 1919)

A rendelet szerint a történelmet - hasonlóan a Magyarországon müködő siketintézetekhez - 7. és 8 . évfolyamban tanították, amire heti 2 óra volt kijelölve. Az alábbi témakörök voltak a 7. osztályban történelem tantárgyból:

- a csehszlovák állam főbb eseményei és legjelentősebb személyiségei a legko- 
rábbi idők óta (Hlavní děje státu československého od nejstarších dob seskupeny kol nejvýznamnějších osob),

- rövid említés azokról a nemzetekröl és birodalmakról, amelyek történelme öszszefüggött a hazai történelemmel (stručné zmínky o národech a řiších, jejichž dějiny souvisely s dějinami domácími).

A 8. osztályban - szintén heti 2 órában - az alábbi tananyagokat írták elő történelem tantárgyból:

- az emberiség fejlödésének rövid ismertetése (Stručný výklad vývoje člověka divoch, lovec, kočovnik, zemědéle. obchodník atd.),

- az ősi nemzetek (egyiptomiak, zsidók, görögök, rómaiak) története (kulturní obrázky dějin starověkých národů - Egypt'ané. Židé, Řekové, Rimané),

- a kereszténység fejlödése államunkban (vývoj křest’anství v našem státě),

- föbb találmányok és felfedezések a középkorban (hlavní vynálezy a objevy ve středověku),

- kulturális képek a középkorból (kulturní obrázky ze středověku),

- általános állampolgári ismeretek (základní poznatky občanské nauky) (Věstník ministerstva školství a národní osvěty. 37.580. 6/IX. 1919.).

Jelentős fordulópont volt az oktatás területén az 1924-es év és ehhez kapcsolódóan a siketoktatás átszervezése. Minden intézetben bevezették kötelező tanítási módszer gyanánt az auditív-verbális (más néven német) módszert. Az Oktatásügyi és Nemzeti Népművelődési Minisztérium 1928-ban a Csehszlovák Köztársaság egész területén müködö összes iskola számára egységes tantervet határozott meg (Pleva 1994, 49). Ezeket a változásokat a 226/1922-es számú kis iskolai törvény néven is ismert törvény idézte elő. A nevezett törvény a következő változásokat rögzítette: módositotta az elemi népiskolák és polgári iskolák tantervét. A nemzeti kisebbségek iskoláiban kötelezővé tette a cseh, illetve szlovák nyelv tanítását heti 3 órában. A kis iskolai törvényt 1925-ben módosították, bevezették a 14 éves korig tartó tankötelezettséget, az elemi népiskolát nyolcosztályossá alakították át (Csicsay 2002, 40).

1932-ben a Prágai Magyar Hírlapban megjelent cikk a legideálisabbként a szlovák nyelvü siketiskolák közül egyedül a körmöcbányait emelte ki, ahol szakiskola is állt a végzett növendékek részére, a cipész-, az asztalos- és szabómesterség elsajátításának lehetőségével (Rehorovszky 1932, 4).

\section{Komáromi siketintézet}

Ahogy az 1919. szeptember 6-án megjelent, a prágai Oktatásügyi és Nemzeti Népművelődési Minisztériumnak a Szociálisügyi Minisztériummal együtt kiadott „a siketnéma állami intézetek szervezeti státuszáról" szóló rendelete kimondta, először Jolsván müködött külön tagozat a magyar hallássérült tanulók számára.

Ez a magyar tagozat rövid életű volt. A jolsvai tagozat földrajzi fekvése és az erös szlovák nyelvi közege miatt Prágában úgy döntöttek, hogy a zömében magyarlakta Komáromba helyezik át az intézetet, ahol önálló magyar tannyelvű intézetet létesítenek. Ennek lebonyolításával Miskey Károly (Karol Miškey) volt körmöcbányai, 
majd jolsvai siketintézeti tanárt bízták meg. Ö el is kezdte a munkát, de nem sikerült megfelelő helyiségeket szereznie. A tanulóknak az 1920-1921-es tanév elején vissza is kellett térniük szüleikhez, és Miskey Károly is visszament Jolsvára tanitani (Pleva 1994, 56).

Az intézet új igazgatóját Körmöcbányáról nevezték ki Szász József személyében, 1920. október 19-én. Az ő nevéhez füződik a minisztérium által kijelölt épületben az osztálytermek kialakítása a kölcsönbe vett bútorokkal. A tanítás 1921. február 4-én kezdődött meg, kezdetben 12 tanulóval (Pleva 1994, 56).

Gyönyör József Terhes örökség címü müvében az alábbi adatokat találjuk a komáromi siketintézetben járó magyar tanulók számáról: az 1921/1922-es tanévben 3 osztály müködött összesen 38 tanulóval. Az 1927/1928-as tanévben 6 osztályban összesen 61 tanuló járt. Az 1930/1931-es tanévben 8 osztály müködött 79 tanulóval, az 1933/1934-es tanévben pedig 9 osztályba járt 105 tanuló. Az utolsó Komáromban töltött tanévben pedig (1937/1938) 8 osztályban 100 tanuló járt, és ekkor a hallássérült tanulók harmada ,ruszinföldi” is volt (Gyönyör 1994,169; Nehéz 1939, 6).

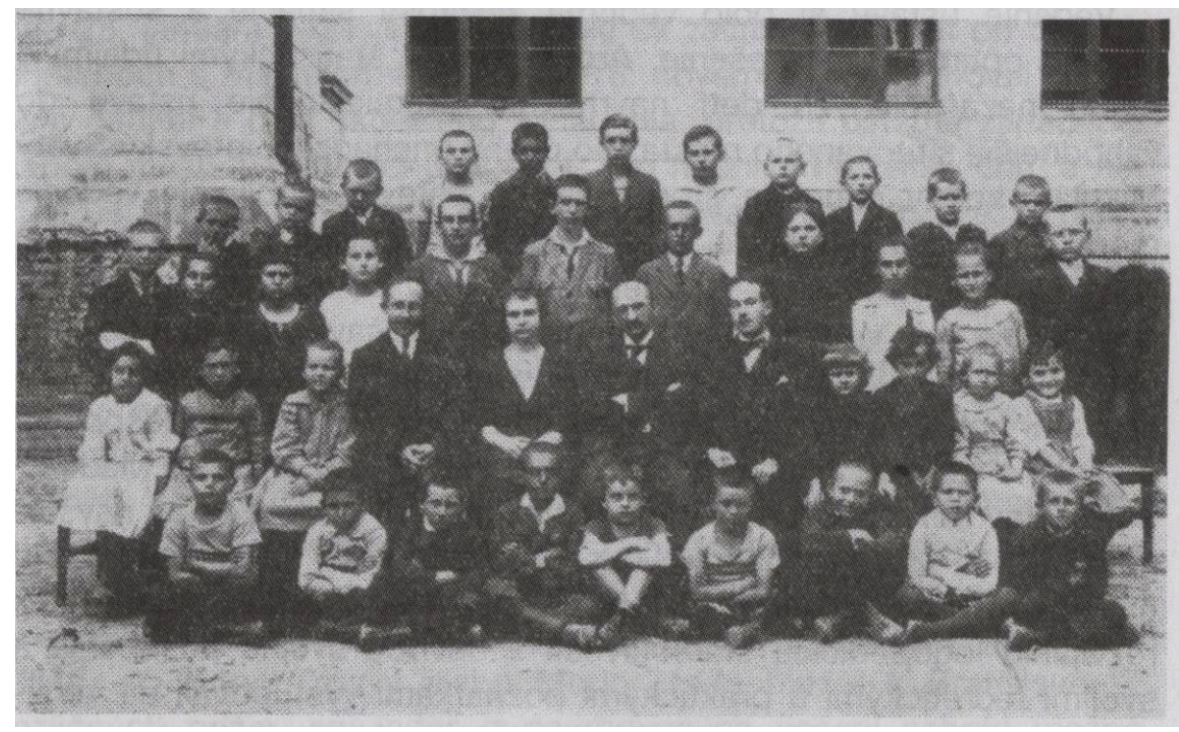

1. ábra: A komáromi siketintézeti tanulói csoportkép (Forrás: Pleva 1994, 56).

A megfelelö épület hiánya miatt felmerült az intézet Érsekújvárra való költözésének gondolata. Végül az intézetben 1926-ban kibővitették a helyiségek számát, így az osztályok száma és az újonnan felvehető tanulók száma is bővült. Egy 1928-ból fennmaradt hirdetmény szerint a magyar nemzetiségüek egész Csehszlovákia területéről kizárólag a komáromi intézetbe kérhették felvételüket. A felvételre jelentkezhettek a „7. életévüket betöltött magyar nemzetiségü siketnéma gyermekek, kik e fogyatkozáson kívül más, őket a tanulásra alkalmatlanná tevő hibában nem szenvednek" (Magyar Tanító 1928). A többi siketintézethez képest a komáromi a 
bentlakás szempontjából volt rosszabb helyzetben, ugyanis a diákoknak különböző családoknál kellett megszállniuk a tanulmányaik alatt. Ez a probléma aztán 1929ben megoldódott, az internátus rendelkezésre állt, amivel a messzebbröl érkező tanulóknak nyújtott bentlakást és ezáltal a tanulók számát is bővíthették.

1934-ben ismét felmerült az intézet költöztetése Érsekújvárra, ugyanis Komárom iskoláinak a befogadóképessége egyre kisebb lett. Ez a kérdés azonban megint lekerült a napirendröl.

Az első bécsi döntés után megint felmerült az intézet költözésének kérdése. Az intézet, amely eddig az egyik katonai kincstári épületben kapott hajlékot, kénytelen volt elköltözni, mert a magyar katonai rendszabályok megkövetelték azt, hogy a katonai épületekkel szorosan összefüggő helyiségekben polgári intézmény nem lehet. A bécsi döntéssel magyar kézre került városok közül Léva és Losonc jelentkezett, hogy az intézetet városukba költöztessék. Mindkét város kész épületet ajánlott fel, Léván pedig még pénzt is gyüjtöttek a siketintézet átköltöztetési költségeire.

Komárom azonban mindent elkövetett, hogy maga számára tartsa meg az iskolát, amelynek „az elvesztése óriási mértékben sújtaná a várost, úgy erkölcsileg, mint anyagilag. A komáromi siketnéma intézet a Felvidék egyetlen ilynemű intézménye, amelynek a növendékei nemcsak a környező vármegyékböl, hanem messze Kárpátaljáról is ide rekrutálódtak. Kulturális szempontból egyik büszkesége Komáromnak ez a messze földön híres iskola, de gazdasági tekintetben is óriási jelentöséggel bír a várost illetőleg. Komárom iparosainak s kereskedőinek évi 200.000 pengő forgalmat jelent az intézet ottléte, gazdasági szempontból is nagy veszteséget jelentene tehát, ha a város kénytelen volna megválni tőle." Fülöp Zsigmond komáromi polgármester feliratban kérte a kultuszminisztériumtól, engedje meg, hogy amíg az intézetnek nincs megfelelő saját épülete, a komáromi mezőgazdasági szakiskola jelenleg üresen álló épületeiben kapjon elhelyezést. Ilyen irányú kérelemmel járt el a polgármester Jaross Andornál, a felvidéki ügyek tárca nélküli miniszterénél és Szilassy Béla államtitkárnál, valamint Zsindely Ferenc miniszterelnökségi államtitkárnál, akik valamennyien megígérték támogatásukat ebben az ügyben (Nehéz 1939, 6).

Végül - a losonci kötődésü dr. Szilassy Béla hathatós közbenjárására - az a döntés született, hogy a komáromi siketintézetet Losoncra költöztetik a volt állami tanítóképző intézet épületébe. Ezzel megszűnt a majd húsz évig működő intézet, ahol 1219 tanuló kapott magyar nyelvü oktatást (Pleva 1994, 57).

\section{Zárszó}

Az I. Csehszlovák Köztársaság magyar nyelvü siketintézménye történetének további feldolgozása a jövőben folyó kutatások feladata lesz. A jelen tanulmány célja az volt, hogy röviden felvázolja a Komáromban müködő siketiskola történeti hátterét és müködését, illetve ezáltal alapul szolgáljon a két világháború közötti csehszlovák siketoktatás-történeti kutatásoknak. 


\section{Források}

A Siketnémák Körmöczbányai Államilag segélyezett Intézetének értesitői. Országos Pedagógiai Könyvtár és Múzeum. E1713.

Věstník ministerstva školstvi a národní osvěty. 37.580. 6/IX. 1919.

Zákon č. 226/1922 Zb. Malý školský zákon

\section{Irodalom}

Csicsay Alajos (2002): Iskolatörténet. Dunaszerdahely.

Gyönyör József (1994): Terhes örökség - A magyarság lélekszámának és sorsának alakulása Csehszlovákiában. Bratislava, Madách-Posonium.

Hercsuth Kálmán (1904): Az intézet keletkezése és az elmúlt két tanév története. A Siketnémák Körmöczbányai Áll. s. Intézetének értesítője. 1903-1904. 1-8. Országos Pedagógiai Könyvtár és Múzeum. E1713.

Herzog Emil (1894): A zsidók története Liptószentmiklóson. Budapest.

Hirdetmény. Magyar Tanító, 1928, 3/14-15, 352.

Hírnök, 1839, 3/53, 1839.07.04. 1.

Klis Lajos (1901): Közérdekű tudnivalók siketnémákról. Siketnémák Közlönye, 1901, 1/4, 34-36.

Körmöcbányai siketintézet értesítője, (1904): A Siketnémák Körmöczbányai Áll. s. Intézetének értesítője. 1905-1906. 26. Országos Pedagógiai Könyvtár és Múzeum. E1713.

Nehéz Ferenc (1939): A Magyar Hiszekeggyel búcsúztak a tanévtöl a komáromi siketintézet növendékei. Felvidéki Magyar Hírlap, 1939.07.02. 6.

Nemzeti Ujság, 1843, 38/51, 1843.05.30. 1.

Pleva, Ján (1994): Rozvoj organizovanej starostlivosti o sluchovo postihnutých na Slovensku. Historický náčrt. I. 106.

Popély Gyula (1998): A magyar iskolaügy kálváriája (Cseh)szlovákiában 1918-1945. In: A (cseh)szlovákiai magyar müvelődés története 1918-1998. II. Oktatásügy - közmüvelődés - sajtó, rádió, televizió. Budapest, 5-93.

Pukánszky Béla István (2019): A szlovákiai pedagógus identitásvizsgálat történeti forrásai. In: Kisebbségi helyzet, identitás és müveltség. A szlovákiai magyar pedagógusok társadalmi önmegvalósítása. Szerk. Horváth Kinga, Tóth Péter, Németh András. Komárom: Selye János Egyetem.

Rehorovszky Jenő (1932): A süketnéma gyermekek világa. Prágai Magyar Hírlap, 1932.03.30. 4.

Vavreková, Iveta (2014): Jazyk a myslenie v tichom svete. In: 9. Študenská Vedecká Konferencia. Zborník plných príspevkov. Szerk. Martin Ološtiak. Prešov: Prešovská univerzita v Prešove, 499-509.

Vojtechovský, Roman (2011): Úvod do kultúry a sveta Nepočujúcich. Bratislava: Two Brothers Company. 